Editorial

\title{
Energy Processes, Systems and Equipment
}

\author{
Izabela Sówka ${ }^{1, * \mathbb{D}}$, Sławomir Pietrowicz ${ }^{2, *(\mathbb{D})}$ and Piotr Kolasiński ${ }^{2, *(\mathbb{D})}$ \\ 1 Department of Environment Protection Engineering, Faculty of Environmental Engineering, \\ Wrocław University of Science and Technology, 27 Wybrzeże Wyspiańskiego Street, 50-370 Wrocław, Poland \\ 2 Department of Thermodynamics and Renewable Energy Sources, Faculty of Mechanical and Power \\ Engineering, Wrocław University of Science and Technology, 27 Wybrzeże Wyspiańskiego Street, \\ 50-370 Wrocław, Poland \\ * Correspondence: izabela.sowka@pwr.edu.pl (I.S.); slawomir.pietrowicz@pwr.edu.pl (S.P.); \\ piotr.kolasinski@pwr.edu.pl (P.K.); Tel.: +48-71-320-25-60 (I.S.); +48-71-320-36-17 (S.P.); +48-71-320-23-39 (P.K.)
}

check for

updates

Citation: Sówka, I.; Pietrowicz, S.; Kolasiński, P. Energy Processes,

Systems and Equipment. Energies 2021, 14, 1701. https://doi.org/ 10.3390/en14061701

Received: 24 January 2021

Accepted: 16 March 2021

Published: 18 March 2021

Publisher's Note: MDPI stays neutral with regard to jurisdictional claims in published maps and institutional affiliations.

Copyright: (c) 2021 by the authors. Licensee MDPI, Basel, Switzerland. This article is an open access article distributed under the terms and conditions of the Creative Commons Attribution (CC BY) license (https:/ / creativecommons.org/licenses/by/ $4.0 /)$.

\begin{abstract}
The scientific and technical issues related to energy harvesting and conversion are inseparably bound to the issues of environmental protection. Energy conversion systems and devices that are applied for converting the chemical energy contained in different fuels into heat, electricity, and cold in industry and housing are sources of different gases and solid particle emissions. Thus, the development of different technologies for energy conversion and environmental protection that can be jointly applied to cover growing energy needs has become a crucial challenge for scientists and engineers around the world. Progress in the precise description, modeling, and optimization of physical and chemical phenomena related to these energy conversion systems is a key research and development field for the economy. Legal and social issues that are affecting key aspects and problems related to the energy conversion and power sector are also significant and worth investigating. The aim of Energy Processes, Systems and Equipment Special Issue is to publish selected high-quality papers from the XV Scientific Conference POL-EMIS 2020: Current Trends in Air and Climate Protection-Control Monitoring, Forecasting, and Reduction of Emissions (29-31 March 2021, Wrocław) and other papers related to the field of energy conversion.
\end{abstract}

Keywords: energy conversion; fuels; energy storage; ecological and legal aspects

Since the beginning of humankind, energy has been the most important need for each human and living being. Consequently, the most important human energy need is the primary chemical energy contained in food. However, modern humans also have a very high demand for high-quality energy products such as electricity, high- and low-temperature heat, and mechanical power. For many years, it has been observed that this demand is constantly growing, which is undoubtedly due to the increasing number of energy receivers and the ease of access to various energy products [1,2]. The increase in energy demand applies to all areas of the economy, i.e., industry, transport, and households [3,4]. For this reason, in many countries, investments related to the implementation of new large power plants and smaller dispersed energy systems along with the development of innovative technological solutions that minimize environmental impact are necessary [5-11]. The development of different means of energy conversion that can be applied to cover growing energy needs and to increase the power and efficiency of generating sources has become a crucial challenge for scientists and engineers around the world, making the power industry, in which operation is based on subsequent energy conversion processes, one of the most important fields of the local, national, and global economy today.

The constantly growing energy generation is reflected in the increasing consumption of different energy carriers, such as fossil fuels, and over the last few decades, increasing attention has been paid to existing fuel resources and the possibility of their depletion in the future. Attention was paid to the development of technologies enabling energy harvesting from alternative sources (renewables and waste) [12]. Increased activity in this area led to 
the development of many innovative and efficient energy conversion technologies over the last few decades, the use of which minimizes the negative impact on the environment. International legal regulations related to the necessity of alternative energy usage have been introduced, and social campaigns aimed at educating consumers about the need for energy consumption rationalization and measures of energy consumption minimizing have also been launched.

Despite the growing usage of alternative energy sources, many large power plants worldwide are still based on fossil fuels [13]. Consequently, problems related to environmental protection, i.e., emissions of greenhouse gases and solid pollutants released during the combustion of different fuels, are of great importance. The need to reduce the emission of harmful substances into the atmosphere has been conditioned by international legal obligations (EU directives, EURO standards, and others) [14,15]. Works on highly efficient technologies that reduce the emission of these substances are setting trends in modern research in the field of energy conversion. Among others, effective electrostatic precipitators [16], heavy metal capture [17], NOx reduction [18], and oxy-fuel technologies [19] can be mentioned. However, in the case of industry, meeting stringent emission standards is becoming increasingly technically difficult, as well as more cost- and energy-intensive. One of the possible solutions is to limit the share of manufacturing processes that require fossil fuel combustion. In many systems, however, this task is very difficult or impossible to perform for technical (i.e., in selected technological processes, the energy obtained from fossil fuel combustion is the only energy source that can be applied) and economic reasons because it is connected with expensive investments. For many developing countries that do not have an infrastructure based on the use of renewable energy or nuclear power, the possibility of minimizing the share of fossil fuel combustion processes is very limited.

In addition to the increased use of renewable and waste energies, other prospective means of reducing fossil fuel consumption are activities related to the diversification of energy systems [20], supporting prosumer activities [21], better energy management [22], and increasing the efficiency of energy conversion processes and energy consumption [23]. It should be remembered that the use of alternative energy resources is not always easy. In some cases (e.g., use of hydrogen), the harvesting technology is still imperfect [24]. Another problem is social resentment towards some technologies, such as municipal waste incineration plants [25]. Establishing proper cooperation between machines and devices using alternative energy sources and the energy grid of the country is also an important challenge. In particular, this concerns matching the energy supply and demand characteristics, as the place of energy generation is not always near to where the demand occurs. It is then necessary to transfer energy to the consumer through an energy grid which has specified requirements related to the quality and quantity of transferred energy. Especially for systems harvesting energy from alternative sources, these requirements are not always met [26,27]. However, the efficient and sustainable use of alternative energy sources is necessary. In addition to many of the positive aspects related to environmental protection, there are other important reasons. Energy safety is one of them. By using alternative energy and local fossil fuel sources, there is the possibility of virtual power plant system implementation [28]. Such a system could cover the local energy demand and supply the energy in the case of a fuel crisis, natural disaster, or the failure of the national energy system. It is expected that energy consumption will grow in the future, which may have a negative impact on the natural environment. Therefore, special focus should be paid to the development of emerging clean energy conversion technologies that can potentially be applied in the near future for energy generation. These technologies include large scale systems, such as, for example, combined cycle gas turbines (CCGT) or thermonuclear reactors like the ITER (international thermonuclear experimental reactor), as well as smaller power systems that can be applied in energy clusters (e.g., hydrogen systems, solar panels, batteries, and other energy storage devices).

All in all, progress in the precise description, modeling, and optimization of physical and chemical phenomena related to energy conversion processes bound to large and dis- 
persed power systems is a key research and development field for the economy. Detailed analysis related to individual input parameters and components that are directly or indirectly influencing the energy conversion chain should be conducted to achieve the final effect of a highly efficient and environmentally friendly power industry. Legal and social issues that are affecting the key aspects and problems related to the energy conversion and power sector are also significant and worth investigating. The aim of Energy Processes, Systems and Equipment Special Issue is to publish selected high-quality papers from the XV Scientific Conference POL-EMIS 2020: Current Trends in Air and Climate ProtectionControl Monitoring, Forecasting, and Reduction of Emissions (29-31 March 2021, Wrocław) and other papers related to the field of energy conversion.

Author Contributions: Conceptualization, I.S., S.P., and P.K.; writing—original draft preparation, I.S., S.P., and P.K.; writing-review and editing, I.S., S.P., and P.K. All authors have read and agreed to the published version of the manuscript.

Funding: This research received no external funding.

Conflicts of Interest: The authors declare no conflict of interest.

\section{References}

1. Bercu, A.-M.; Paraschiv, G.; Lupu, D. Investigating the Energy-Economic Growth-Governance Nexus: Evidence from Central and Eastern European Countries. Sustainability 2019, 11, 3355. [CrossRef]

2. Mardani, A.; Streimikiene, D.; Nilashi, M.; Arias Aranda, D.; Loganathan, N.; Jusoh, A. Energy Consumption, Economic Growth, and $\mathrm{CO}_{2}$ Emissions in G20 Countries: Application of Adaptive Neuro-Fuzzy Inference System. Energies 2018, 11, 2771. [CrossRef]

3. Lu, W.-C. Electricity Consumption and Economic Growth: Evidence from 17 Taiwanese Industries. Sustainability 2017, 9 , 50. [CrossRef]

4. Hu, Y.; Guo, D.; Wang, M.; Zhang, X.; Wang, S. The Relationship between Energy Consumption and Economic Growth: Evidence from China's Industrial Sectors. Energies 2015, 8, 9392-9406. [CrossRef]

5. Wang, S.; Li, W.; Dincer, H.; Yuksel, S. Recognitive Approach to the Energy Policies and Investments in Renewable Energy Resources via the Fuzzy Hybrid Models. Energies 2019, 12, 4536. [CrossRef]

6. Fuchs, C.; Marquardt, K.; Kasten, J.; Skau, K. Wind Turbines on German Farms-An Economic Analysis. Energies 2019, $12,1587$. [CrossRef]

7. Kryzia, D.; Kopacz, M.; Kryzia, K. The Valuation of the Operational Flexibility of the Energy Investment Project Based on a Gas-Fired Power Plant. Energies 2020, 13, 1567. [CrossRef]

8. Wang, C.; Yan, Y.; Li, J.; Quan, Y.; Li, S.; Wu, G. Integrated Environmental Effect Assessment on Large Coal-Electricity Production Base and Sustainability Strategy: A Case in Xilin Gol, China. Sustainability 2020, 12, 5943. [CrossRef]

9. Lu, Y.; Khan, Z.A.; Alvarez-Alvarado, M.S.; Zhang, Y.; Huang, Z.; Imran, M. A Critical Review of Sustainable Energy Policies for the Promotion of Renewable Energy Sources. Sustainability 2020, 12, 5078. [CrossRef]

10. Tian, J.; Fang, C.; Qiu, J.; Wang, J. Analysis of Pollution Characteristics and Influencing Factors of Main Pollutants in the Atmosphere of Shenyang City. Atmosphere 2020, 11, 766. [CrossRef]

11. Dettori, M.; Pittaluga, P.; Busonera, G.; Gugliotta, C.; Azara, A.; Piana, A.; Arghittu, A.; Castiglia, P. Environmental Risks Perception Among Citizens Living Near Industrial Plants: A Cross-Sectional Study. Int. J. Environ. Res. Public Health 2020, 17, 4870. [CrossRef] [PubMed]

12. Halkos, G.E.; Gkampoura, E.-C. Reviewing Usage, Potentials, and Limitations of Renewable Energy Sources. Energies 2020, 13, 2906. [CrossRef]

13. Bielecka, A.; Kulczycka, J. Coal Combustion Products Management toward a Circular Economy-A Case Study of the Coal Power Plant Sector in Poland. Energies 2020, 13, 3603. [CrossRef]

14. Waluś, K.J.; Warguła, Ł.; Krawiec, P.; Adamiec, J.M. Legal regulations of restrictions of air pollution made by non-road mobile machinery-The case study for Europe: A review. Environ. Sci. Pollut. Res. 2018, 25, 3243-3259. [CrossRef]

15. Kuklinska, K.; Wolska, L.; Namiesnik, J. Air quality policy in the U.S. and the EU-A review. Atmos. Pollut. Res. 2015, 6, 129-137. [CrossRef]

16. Elkamhawy, A.; Jang, C.-M. Performance Evaluation of Hybrid Air Purification System with Vegetation Soil and Electrostatic Precipitator Filters. Sustainability 2020, 12, 5428. [CrossRef]

17. Karvelas, E.; Liosis, C.; Benos, L.; Karakasidis, T.; Sarris, I. Micromixing Efficiency of Particles in Heavy Metal Removal Processes under Various Inlet Conditions. Water 2019, 11, 1135. [CrossRef]

18. Onrubia-Calvo, J.A.; Pereda-Ayo, B.; González-Velasco, J.R. Perovskite-Based Catalysts as Efficient, Durable, and Economical $\mathrm{NO}_{\mathrm{x}}$ Storage and Reduction Systems. Catalysts 2020, 10, 208. [CrossRef]

19. Hamadeh, H.; Toor, S.Y.; Douglas, P.L.; Sarathy, S.M.; Dibble, R.W.; Croiset, E. Techno-Economic Analysis of Pressurized Oxy-Fuel Combustion of Petroleum Coke. Energies 2020, 13, 3463. [CrossRef] 
20. Gonzales-Zurita, Ó.; Clairand, J.-M.; Peñalvo-López, E.; Escrivá-Escrivá, G. Review on Multi-Objective Control Strategies for Distributed Generation on Inverter-Based Microgrids. Energies 2020, 13, 3483. [CrossRef]

21. Gram-Hanssen, K.; Hansen, A.R.; Mechlenborg, M. Danish PV Prosumers' Time-Shifting of Energy-Consuming Everyday Practices. Sustainability 2020, 12, 4121. [CrossRef]

22. Allen, J.; Halberstadt, A.; Powers, J.; El-Farra, N.H. An Optimization-Based Supervisory Control and Coordination Approach for Solar-Load Balancing in Building Energy Management. Mathematics 2020, 8, 1215. [CrossRef]

23. Perea-Moreno, A.-J.; Manzano-Agugliaro, F. Energy Saving at Cities. Energies 2020, 13, 3758. [CrossRef]

24. Felseghi, R.-A.; Carcadea, E.; Raboaca, M.S.; TRUFIN, C.N.; Filote, C. Hydrogen Fuel Cell Technology for the Sustainable Future of Stationary Applications. Energies 2019, 12, 4593. [CrossRef]

25. Achillas, C.H.; Vlachokostas, C.H.; Moussiopoulos, N.; Banias, G.; Kafetzopoulos, G.; Karagiannidis, A. Social acceptance for the development of a waste-to-energy plant in an urban area. Resour. Conserv. Recycl. 2011, 55, 857-863. [CrossRef]

26. Yap, K.Y.; Sarimuthu, C.R.; Lim, J.-Y. Virtual Inertia-Based Inverters for Mitigating Frequency Instability in Grid-Connected Renewable Energy System: A Review. Appl. Sci. 2019, 9, 5300. [CrossRef]

27. Vadi, S.; Padmanaban, S.; Bayindir, R.; Blaabjerg, F.; Mihet-Popa, L. A Review on Optimization and Control Methods Used to Provide Transient Stability in Microgrids. Energies 2019, 12, 3582. [CrossRef]

28. Sikorski, T.; Jasiński, M.; Ropuszyńska-Surma, E.; Węglarz, M.; Kaczorowska, D.; Kostyla, P.; Leonowicz, Z.; Lis, R.; Rezmer, J.; Rojewski, W.; et al. A Case Study on Distributed Energy Resources and Energy-Storage Systems in a Virtual Power Plant Concept: Technical Aspects. Energies 2020, 13, 3086. [CrossRef] 